\title{
Species Diversity of Decapods Associated with Living and Dead Reef Coral Pocillopora meandrina
}

\author{
S. L. Coles \\ Environmental Department, Hawaiian Electric Company, Inc., P. O. Box 2750, Honolulu, Hawaii 96840, USA
}

\begin{abstract}
The decapod communities associated with live and dead specimens of the reef coral Pocillopora meandrina Dana in Hawaii were investigated. Species composition of decapods shifted gradually from dominance by large sized symbiotic species to minute, facultatively associated nonsymbionts as host corals died from an environmental disturbance. Species diversities of nonsymbiont communities were substantially greater than diversities of symbiont communities on live corals. Statistically significant linear relationships were found between live coral surface area and numbers of species and individuals of symbiotic decapods. Similar relationships were recorded between nonsymbionts and dead coral surface area. The compositions and sizes of the respective communities are determined by the space and nature of their habitats. The symbiont community is a highly predictable association finely turned to its habitat principally by trophic requirements. By contrast, the composition of the more diverse nonsymbiont community appears to be determined by random colonization from the general reef environment, filling to capacity the habitat space provided by the dead coral. The contrasting characteristics of the two decapod communities are discussed in terms of various theories of coral reef diversity.
\end{abstract}

\section{INTRODUCTION}

A variety of determining factors have been proposed to account for the high species diversity of coral reef systems. An adequate explanation is complicated by the possibility that many factors which have been proposed to increase species diversity may be acting simultaneously on a reef community. High primary productivity rates (Connell and Orias, 1964) may enable development of high trophic diversity (Kohn, 1971). High spatial heterogenity within coral reefs may promote high species diversity (Abele, 1974; Abele and Patton, 1976) in direct relation to the increased area provided (Preston, 1960; MacArthur, 1965; MacArthur and Wilson, 1967). Predator pressure may reduce the monopolization of space and resources by the most efficient competitors (Paine, 1966; Porter, 1972b; Menge and Sutherland, 1976; Kushlan, 1976; Day, 1977; Lubchenco and Menge, 1978). The long term environmental stability attributed to tropical conditions may promote biological interaction and interspecific competition (Klopfer and MacArthur, 1961; Sanders, 1968; Slobodkin and Sanders, 1969; Johnson, 1970), resulting in higher species diversity. Conversely, stochastic events such as the effects of periodic physical disturbances which may reopen living space (Connell, 1973, 1978; Grigg and Maragos, 1974; Grassle, 1973), and the element of chance colonization
(Sale, 1978) may be more important factors determining the diversity on coral reefs.

Hermatypic corals visually dominate tropical reefs and form the substratum which provides the habitat for most other reef macro-organisms. Many studies of coral reef diversity have therefore been limited to reef corals, and coral ecologists have extrapolated or implied general explanations for the high diversity of coral reefs based upon observations of this single taxonomic group (Loya, 1972; Porter, 1972a, b; Connell, 1973, 1978; Grigg and Maragos, 1974; Maragos, 1974; Scatterday, 1977). Other studies have investigated other taxonomic groups in coral reefs and attempted to relate findings to various physical or biological factors affecting those populations (Sanders, 1968; Kohn, 1971; Grassle, 1973; Abele, 1974, 1976; Day, 1977). However, few studies have interrelated populations of non-coral reef organisms to habitats provided by living hermatypic corals (McCloskey, 1970; Abele, 1976; Abele and Patton, 1976), and none have determined changes in species diversity of non-coral organisms that may accompany stress-related alteration of a reef coral population.

The present study investigates the diversity of decapod crustaceans associated with the reef coral Pocillopora meandrina Dana before, during, and after a physical stress which killed the living tissue surface of the coral host. The net result of coral death is an 
abrupt shift in the characteristics of the decapod community associated with the coral. The observed changes in this simplified community provide insight into the relative importance of many of the various factors which have been proposed to influence coral reef diversity.

\section{MATERIAL AND METHODS}

Pocillopora meandrina Dana is an erect, branching reef coral which dominates nearshore reefs in open water throughout the Hawaiian Islands. The coral grows up to $40 \mathrm{~cm}$ in diameter in a hemispherical to hemi-elipsoid shape, and contains meandering open spaces approximately $2 \mathrm{~cm}$ wide within its branched structure. The live coral, therefore, provides a semienclosed space which is utilized primarily by decapod crustaceans (Barry, 1965).

I collected large (ca $30 \mathrm{~cm}$ diameter) specimens of Pocillopora meandrina from two stations near the construction site of an offshore outfall pipeline for the Kahe Generating Station, Oahu, Hawaii. A description of the area can be found in Jokiel and Coles (1975). Three colonies were collected from each station during June, 1976, July, 1977, and August, 1977. Corals in the area were exposed to considerable physical shock, siltation and turbidity stress from offshore construction activities between the first and second collection, resulting in substantial mortality of $P$. meandrina during this period. Nearly all corals of this species had died prior to the August 1977 collection.

Corals were collected by enclosing them in plastic bags and breaking the intact colonies from their substratum with a diver's tool and hammer. The bagged corals were then transported to the laboratory and held frozen until analysis. The long and short diameters and height of each colony were measured to the nearest $\mathrm{cm}$, then the corals were broken apart and washed over a $0.5 \mathrm{~mm}$ mesh screen. Organisms collected from the washings were sorted and identified under a dissecting microscope. All pieces were closely inspected to assure that all motile organisms were collected.

I calculated volume enclosed by each coral using the formula for a three dimensional elipse: $v=4 / 3 a b c$, where $a$ and $b$ are the long and short diameters and $c$ is the height of the coral above the substratum. The value calculated approximates the combined volume of the coral skeleton plus the space between branches.

Coral head volume as determined above, while easily measured, is only a rough estimator of the habitable space available to organisms living on the coral's surface. A more preferable technique would determine the actual surface area. However, techniques which estimate surface areas using thin surface layers (Johannes et al., 1970; Marsh, 1970) are tedious and insufficiently precise to use on a coral with a surface as complex as Pocillopora meandrina. A previous study (Barry, 1965) estimated habitat space for this species by indirectly determining the volume between branches. Another (Abele and Patton, 1976) mathematically estimated the surface area as a function of the volume by the formula Surface Area $=$ Volume $^{2 / 3}$. I estimated total coral surface area by this formula in the present study, recognizing the following limitations: (1) Surface area so determined is proportional, rather than equal to the true surface area; (2) For the proportionality to hold consistently across a range of coral sizes, the branches of the coral must grow in a regular, repetitive fashion. Such regularity in growth form was demonstrated for $P$. meandrina by Barry (1965).

I estimated live and dead coral surface areas by visually inspecting each colony and multiplying the coral surface area by the proportion of the colony that was covered or not covered with coral tissue. Most corals broken from the reef came away with varying amounts of dead coral substratum. This material was chipped away from the coral head and weighed after any decapods remaining on it were removed, in order to determine any relationship between numbers of decapods and amount of coral rubble inadvertently included in the samples.

\section{RESULTS}

\section{Pocillopora meandrina Habitat}

Corals collected for the study reflected the general conditions for most of the Pocillopora meandrina populations at the stations at the times of collection. Those sampled in June, 1976 were in apparently healthy condition, fully covered with live coral tissue and were taken with a minimum of dead reef substratum. Continual exposure to turbidity and sedimentation caused by offshore construction activities produced a gradual decline in $P$. meandrina in the area during the following year. By July, 1977 construction had ceased and normal water clarity was restored, but most $P$. meandrina heads in the area had died and their dead branches were coated with fine sediment or were the substratum for a variety of epiphytic algae. A few heads which were still partly alive were collected at this time, and these ranged from $12 \%$ to $88 \%$ covered with coral tissue (Table 1). The corals collected in August, 1977 were completely dead except for one head which still had live tissue on less than $1 \%$ of the total head area.

\section{Symbiotic Decapod Community}

Live corals of the genus Pocillopora provide a habitat 
for a variety of symbiotic organisms. These include fish, echinoderms and molluscs, but the symbiotic community is principally composed of decapod crustaceans (Castro, 1976; Patton, 1976). Pocilloporid corals are restricted to the Indo-Pacific region, and the compositions of symbiotic communities have been studied in the waters of western Central America (Garth, 1974a; Abele, 1976; Abele and Patton, 1976; Glynn, 1976; Castro, 1978), Hawaii (Barry, 1965; Preston, 1971, 1973), the Marshall Islands (Garth, 1964; Knudsen, 1967), the Great Barrier Reef (Patton, 1966, 1974), and the Indian Ocean (Garth, 1974b).

The decapods associated with Pocillopora meandrina in Hawaii include seven species of xanthid crabs, two species of alpheid shrimp and one pontoniid shrimp which live on the coral's surface (Barry, 1965), and two hapalocarcinid species which form their own habitats within the coral skeleton (Castro, 1976; McCain and Coles, 1979). The xanthid Trapezia intermedia is the most frequently found of these associates (Table 1) occuring on $97 \%$ of a full size range of $P$. meandrina heads sampled in the Kahe area (Coles, 1977, unpublished) and on $85 \%$ of $P$. meandrina sampled in Kaneohe Bay, Hawaii (Barry, 1965). T. intermedia is generally the earliest colonizer of small $P$. meandrina colonies, while larger $P$. meandrina are usually shared with at least one other Trapezia species, Alpheus lottini and Synalpheus charon. These species undergo sex-pair formation and engage in agonistic behavior which excludes other conspecific adults (Preston, 1971, 1973; Glynn, 1976).

Hapalocarcinus marsupialis and Pseudocryptochirus kahe reside in galls or burrows formed within the coral skeleton (Potts, 1915; Castro, 1976; McCain and Coles, 1979), and therefore are not considered here as functional members of the ectocommensal symbiotic community, even though they are obligate symbionts with Pocillopora meandrina or other pocilloporid corals. The remaining symbiotic species (Domecia, hispida, Actaea speciosa and Harpiliopsis depressus) show no clear indication of pair formation or agonistic behavior between adults, but rather increase their numbers of coral occupants with increasing coral size (Barry, 1965).

\section{Nonsymbiotic Decapods}

Less is known about the communities of decapod crustaceans which are not obligately associated with living corals, but which may utilize the basal areas of live corals or may occupy the skeletons of corals after the corals have died. McCloskey (1970) found only 15 decapods out of a total of 309 noncolonial invertebrate species associated with the ahermatypic coral Oculina arbuscula from the coast of North Carolina. Barry (1965) listed 28 species of nonsymbiotic decapods from

Table 1. Frequencies of symbionts per coral associated with Pocillopora meandrina heads

\begin{tabular}{|c|c|c|c|}
\hline Taxa & $\begin{array}{c}\text { Barry, } 1965 \\
(n=92)\end{array}$ & $\begin{array}{l}\text { Frequencies: } \\
\text { Coles, 1977, unpubl. } \\
\quad(n=168)\end{array}$ & $\begin{array}{l}\text { Present study } \\
\quad(n=18)\end{array}$ \\
\hline \multicolumn{4}{|l|}{ Phylum Arthropoda } \\
\hline \multicolumn{4}{|l|}{ Class Crustacea } \\
\hline \multicolumn{4}{|l|}{ Order Decapoda } \\
\hline \multicolumn{4}{|l|}{ Tribe Brachyura } \\
\hline \multicolumn{4}{|l|}{ Family Xanthidae } \\
\hline Trapezia digitalis Latrielle & 0.43 & 0.49 & 0.44 \\
\hline T. intermedia Miers & 0.97 & 0.85 & 0.66 \\
\hline T. wardi Serene & 0.49 & 0.66 & 0.66 \\
\hline T. ferruginea Latrielle & 0.04 & 0.47 & 0.50 \\
\hline T. flavopunctata Eydoux and Souleyet & 0.01 & 0.28 & 0.22 \\
\hline Domecia hispida Eydoux and Souleyet & 0.36 & 0.54 & 0.33 \\
\hline Actaea speciosa (Dana) & 0.16 & 0.24 & 0.39 \\
\hline \multicolumn{4}{|l|}{ Family Haplocarcinidae } \\
\hline Hapalocarcinus marsupialis Stimpson & 0.02 & 0.11 & 0.11 \\
\hline Pseudocryptochinus Kahe McCain and Coles & $\cdot$ & 0.26 & 0.17 \\
\hline \multicolumn{4}{|l|}{ Tribe Macrura } \\
\hline \multicolumn{4}{|l|}{ Family Alpheidae } \\
\hline Alpheus lottini Guerin & 0.92 & 0.73 & 0.72 \\
\hline Synalpheus charon (Heller) & 0.89 & 0.47 & 0.17 \\
\hline \multicolumn{4}{|l|}{ Family Pontonidae } \\
\hline Harpiliopsis depressus (Stimpson) & 0.89 & 0.69 & 0.61 \\
\hline
\end{tabular}


Table 2. Frequencies and abundances of most common nonsymbiotic decapods on 18 Pocillopora meandrina heads

\begin{tabular}{|lcc|}
\hline \multicolumn{1}{|c}{ Species } & Frequency & $\begin{array}{c}\text { Total } \\
\text { abundance }\end{array}$ \\
\hline Actaea variolosa & & 21 \\
Alpheus brevipes & 0.44 & 16 \\
A. clypeatus & 0.50 & 104 \\
Calcinus sp. B & 1.00 & 121 \\
Calcinus sp. D & 0.44 & 27 \\
Cryptodromiopsis tridens & 0.44 & 14 \\
Galathea spinosorostris & 0.55 & 99 \\
Paguridae, new genus B sp. B & 0.61 & 14 \\
Perinea tumida & 0.44 & 52 \\
Pilumnus longicornis & 0.83 & 39 \\
Pontoniidae, new genus A sp. B & 0.72 & 30 \\
Pylopaguropsis sp. & 0.44 & 80 \\
Schizophrys hilensis & 0.61 & 11 \\
Synalpheus biungulatus & 0.44 & 18 \\
S. paraneomeris & 0.44 & 33 \\
& 0.50 & \\
\hline
\end{tabular}

Pocillopora meandrina, all of them found on the dead basal areas of live coral colonies. Garth (1964) described symbiotic and nonsymbiotic decapods associated with various corals at Enewetak and commented on the disproportionate representation by the xanthidae in both groups. Patton (1976) lists only four species of facultatively associated decapods on Pocillopora damicornis from Australia, while Abele and Patton (1976) found 55 decapod species, including five recognized symbionts, associated with $P$. damicornis in Panama. However, with the exception of Abele's (1976) study relating species richness of this community to environmental stability, no investigations have been made of relationships between coral associated decapods and physical factors, nor of possible changes in coral associates with succession.

One hundred fifteen species of nonsymbiotic decapods were found in addition to the twelve symbiotic species on the eighteen corals sampled in the present study. The frequencies and abundances of the fifteen most common of these are given in Table 2 . The community was dominated by xanthids, pagurids and alpheids. Prominent among these is Alpheus clypeatus which was found on every coral in nests constructed from algal mats adhering to dead coral branches (Bowers, 1970). On live corals facultatively associated species are relatively few in number and are restricted to non-living basal areas of the coral, while on dead corals many more species and individuals were found throughout the coral head.

\section{Community Effects and Succession}

Nonsymbiotic decapods increased in number while symbiotic decapods became less abundant on corals from each subsequent collection. Kruskal-Wallis anal- yses of variance by ranks were performed to determine whether significant differences in the data occurred between stations or among sampling times (Table 3). No significant differences were found between stations for coral volume, numbers of symbiotic and nonsymbiotic species and individuals, or the total weights of symbiotic decapods associated with a coral. No significant difference in coral head volume was found among sampling periods, but the remaining characteristics showed highly significant differences among sampling times $(P<0.01)$.

The proportion of coral surfaces that were covered with live tissue decreased dramatically with subsequent collections (Table 4). The responses of the symbiotic and nonsymbiotic decapod communities to this change are shown in Figures 1 and 2. Highly significant relationships were found between live surface area and numbers of symbiotic decapod species and individuals, indicating that these types of organisms gradually left the corals as coral tissue coverage diminished. Conversely, nonsymbiotic decapod numbers of individuals and species showed highly significant relationships $(P<0.001)$ with dead coral surface areas, i. e. as corals died and symbionts vacated, nonsymbionts occupied a coral in direct proportion to the space available. Similar analyses indicated no significant relationships between associated organisms and the weights of coral rubble that accompanied corals when collected. Therefore, the numbers of associates were primarily determined by the habitat space available on the coral's surfaces.

Figures 1 and 2 also show the relationships between live or dead coral surface area and the ShannonWeaver information function (Shannon and Weaver, 1949; MacArthur, 1955) and Pielou's evenness index (Pielou, 1966). Although the biological meaning of the Shannon-Weaver Function is ambiguous and it has been criticized as a 'dubious index', (Hurlbert, 1971; Goodman, 1975) it remains in common usage as a convenient way of describing an assemblage of organisms in terms of both numbers of species and the apportionment of individuals among species. This esti-

Table 3. Summary of Kruskal-Wallis tests of differences between stations and among sampling times

\begin{tabular}{|c|c|c|}
\hline Variable & $\begin{array}{c}\text { Significa } \\
\text { Station }\end{array}$ & $\begin{array}{c}\text { Se levels } \\
\text { Sample } \\
\text { time }\end{array}$ \\
\hline Coral volume & 0.89 & 0.43 \\
\hline Numbers of symbiont species & 0.83 & 0.003 \\
\hline Numbers of symbiont individuals & 0.38 & 0.004 \\
\hline Symbiont total weight & 0.63 & 0.0008 \\
\hline Numbers of nonsymbiont species & 0.60 & 0.002 \\
\hline Numbers of nonsymbiont individuals & 0.54 & 0.008 \\
\hline
\end{tabular}




2
2
0
0
0
0
0
0
0
0
0
0

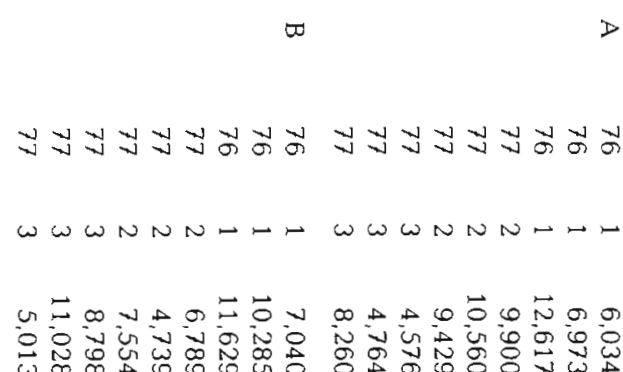

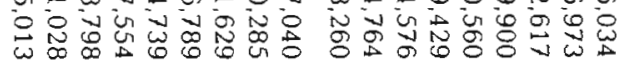

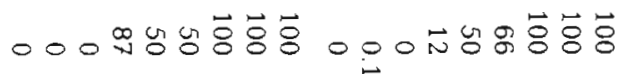

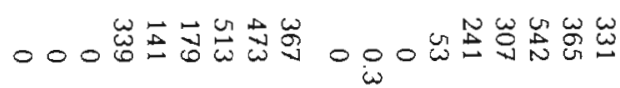

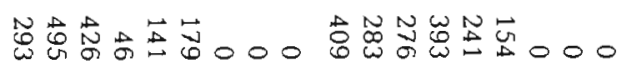

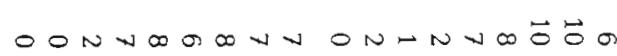

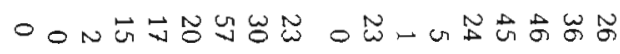

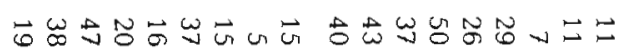

凹芯

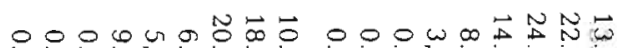

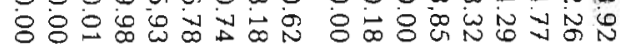

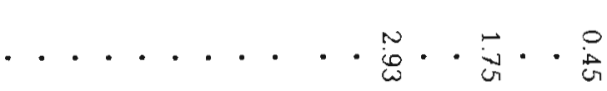

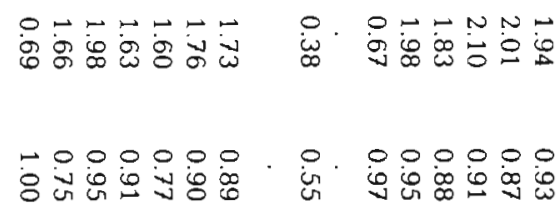

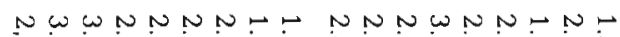

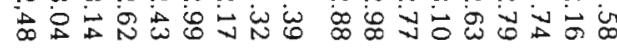

000000000000000000

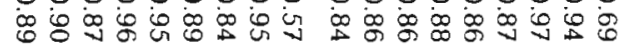

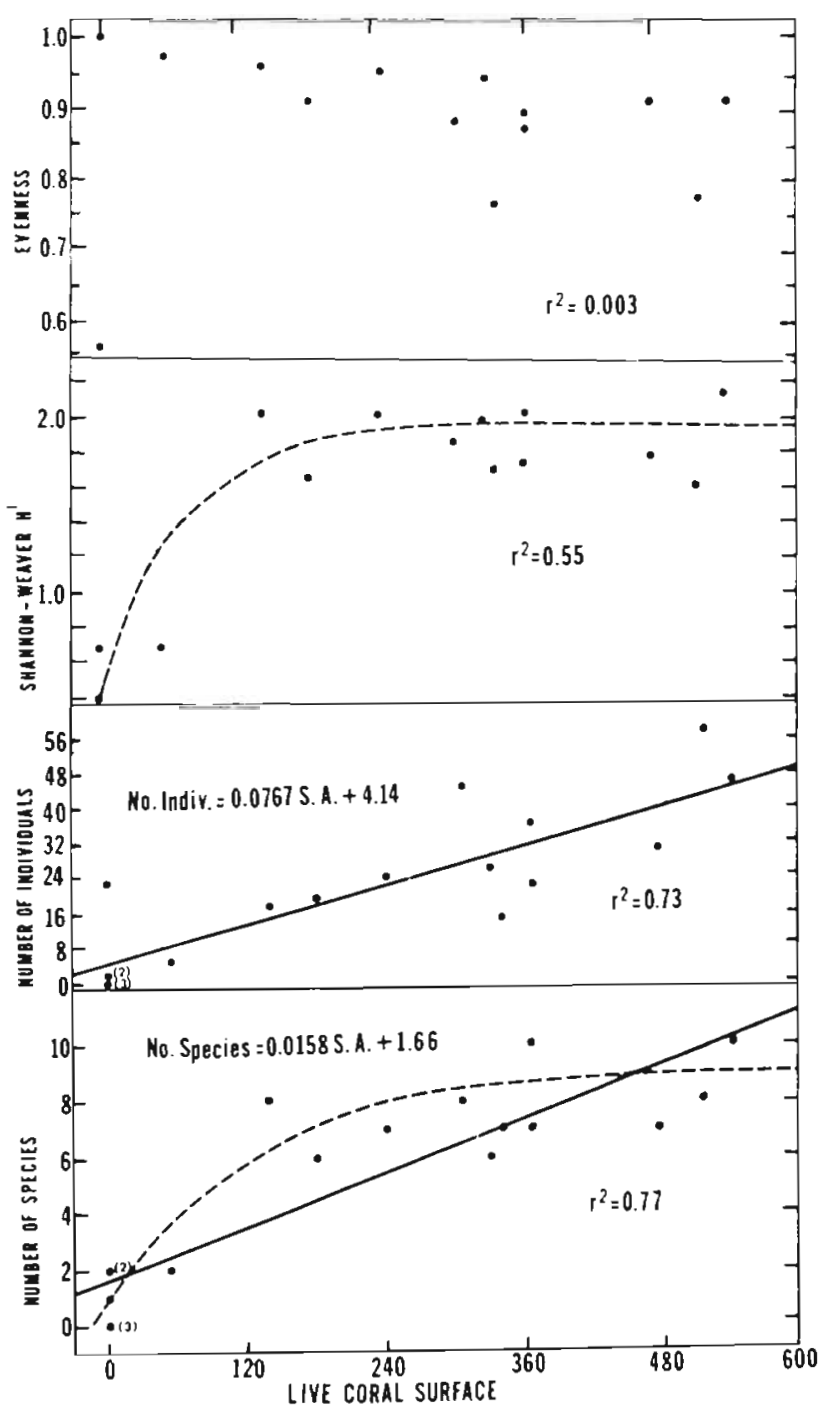

Fig. 1. Symbiotic decapods. Relationships of numbers of species, individuals, Shannon-Weaver $\mathrm{H}^{\prime}$ and Pielou's evenness coefficient values with live coral surface area available on 18 Pocillopora meandrina colonies. Solid lines: significant linear fits determined by regression analyses; dashed lines: visually fitted curvilinear relationships

mate of 'species diversity' is therefore a function of the number of species present and the evenness with which individuals are distributed among species, and, unlike many other diversity indices, is independent of samples' size (Sanders, 1968). Pielou's evenness index expresses the determined diversity estimates as a decimal fraction of what the value would be if all individuals were apportioned equally among all species.

Figure 1 indicates that, in contrast to the significant positive relationship shown between coral surface area and numbers of species and individuals, $\mathrm{H}^{\prime}$ for the symbionts does not change significantly above an estimated coral surface area of about $90 \mathrm{~cm}^{2}$. (F ratio of 


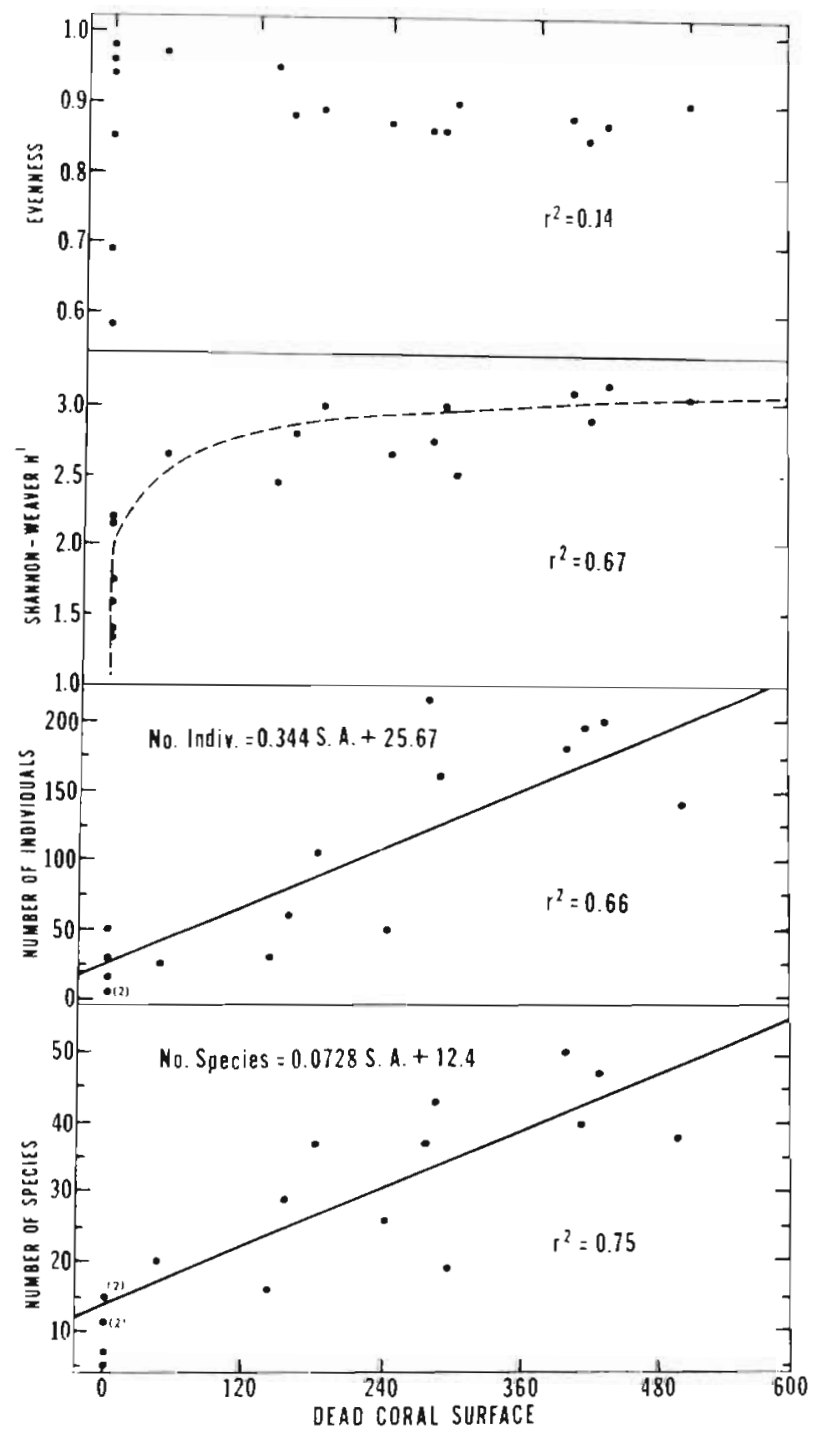

Fig. 2. Nonsymbiotic decapods. Relationships of numbers of species, individuals, Shannon-Weaver $\mathrm{H}^{\prime}$ and Pielou's evenness coefficient values with dead surface area available on 18 Pocillopora meandrina colonies. Solid lines: significant linear fits determined by regression analyses; dashed line: visually fitted

linear regression coefficient $=0.01 ; p=0.94$ ). Since species numbers increase significantly with live coral surface area, an assymptotic $\mathrm{H}^{\prime}$ relationship indicates that relatively few species have proportionate increases in their numbers of individuals, i. e. there is decreasing species evenness with greater live coral surface. Such a relationship is suggested by the plot of Pielou's evenness coefficient in Figure 1. However, the linear regression coefficient of the line corresponding to surface areas greater than $90 \mathrm{~cm}^{2}$ is not significantly different than zero $(F=1.99, p=0.19)$.

Similar analysis for the nonsymbiont decapod community with dead surface areas greater than $30 \mathrm{~cm}^{2}$ indicates a significant positive relationship with $\mathrm{H}^{\prime}(F$ ratio of linear regression coefficient $=6.66, p=0.027$ ) and a negative relationship with evenness that closely approaches significance $(F=4.78, p=0.053)$. The relationship of decreasing evenness with greater available habitat space previously suggested for the symbiont community is therefore more strongly indicated for the nonsymbiont community.

A linear relationship between the total wet weight of the symbiotic community and live coral surface area is also indicated $(F$ ratio of regression coefficient $=$ $171.76, P<0.0001$ ). Average weights of symbiont individuals decreased with decreasing live coral surface area, ranging from (mean $\pm \mathrm{SD}$ ) $0.52 \pm 0.097 \mathrm{~g}$ per individual on corals from the first sampling period to $0.006 \pm 0.0017 \mathrm{~g}$ per individual on the three dead corals from the third sampling period which were found to have any symbionts (Table 4). Nonsymbionts were weighed from Corals 1,4 , and 7 only, and these suggested total weight to increase linearly with dead coral surface area. Weights per individual ranged 0.009 to $0.034 \mathrm{~g}$, substantially less than the more obvious and larger symbiont species. No systematic increase in nonsymbiont individual weight with increased available surface area was found.

\section{DISCUSSION}

Reduction in species richness and diversity are generally the expected responses to physical disturbances in subtidal marine communities, especially in tropical or subtropical regions where the majority of resident organisms are stenotopic (Johannes, 1975). Even a strong critic of the use of diversity indices as indicators of community stability has stated (Goodman, 1975; p. 250) '... it is a truism that any serious ecological perturbation will lead to some extinctions and a reduction of species diversity. Pollution generally leads to a reduction of diversity... However, the results of the present study do not comply with this truism. Although the physical disturbances of siltation and mechanical damage of the coral host did gradually result in the extinction of the normal community of symbionts, the non-symbiont decapod community which replaced them was substantially more rich and diverse, with up to five times the numbers of species and a ShannonWeaver $\mathrm{H}^{\prime}$ value about 1.5 times higher.

These results are comparable to those of Abele (1976), who found more decapod species associated with live Pocillopora damicornis in a fluctuating physical environment than in a stable environment off the Pacific coast of Panama. Although P. damicornis hosts were described as living, the physical stresses in the unstable environment produce sufficient coral damage 
to limit survival of mucus-feeding symbiotic decapods, thereby making space available for nonsymbiont colonization. The same factors - physical damage to host, elimination of symbionts and random colonization by nonsymbionts resulting in a highly diverse community - were found in the Abele (1976) study and the present study. Sublethal stresses on the coral host in Panama acting over a long time have produced results similar to the short-term, man-induced stresses of the present study. McCloskey (1970) also determined the diversity of the invertebrate community associated with the coral Oculina arbuscula off the North Carolina coast to increase with the degree of scouring and sedimentation to which the coral host was exposed. These physical stresses caused the growth form of the host to be modified to create additional habitat for facultative associates.

The progression of events from occupation by symbionts to recolonization by nonsymbiont decapods observed in this study may be considered to be a special case encapsulating within a short time the normal sequences of succession. Pocillopora meandrina grows as discrete colonies which seldom exceed $40 \mathrm{~cm}$ diameter and live a maximum of $10-15$ years (Edmondson, 1929). Even the smallest sized P. meandrina colonies contain a complement of symbiotic decapods, and numbers of species and numbers of individuals of certain symbiont species increase with increasing coral size (Barry, 1965; Preston, 1971, 1973; Coles, 1977, unpublished). However, a population of $P$. meandrina sampled on an Hawaiian reef will have a substantial percentage of dead heads in all size classes, even in areas remote from pollution influence. These dead or dying heads provide habitat for a highly diverse community of facultatively associated decapods. Subsequently, a dead coral skeleton will be overgrown by calcerous algae or penetrated by boring organisms and eroded away, destroying the spatial heterogeneity which enables colonization by the facultative decapod associates. Alternatively, it may provide a substrate for coral settlement and growth and reoccupation by symbionts.

Further comparisons of characteristics of symbiotic decapods to the dominant members of the nonsymbiotic associates are instructive. The symbiotic decapods are conspicuous for their relatively large size, bright or transparent coloration, sexpair formation, agonistic behavior and feeding habits. Average weights per individual of symbiotic decapods in this study were up to 100 times the weights per individual of nonsymbionts, and capapace widths of $25 \mathrm{~mm}$ were not uncommon for the colorful Trapezia species, which are among the largest to be found in the family xanthidae. The symbiont Alpheus lottini (= Crangon ventrosa, Banner, 1953; p. 87) is the 'most spectacular, both in color and size of the Hawaiian alpheid shrimps'. With the exception of the pontoniid Harpiolopsis depressus and the xanthid Domecia hispida, all members of the symbiotic community undergo pairing between sexually mature adults. The Trapezia species engage in active agnostic behavior which excludes other adults of the same species, (Preston, 1971, 1973) although the actual members of the cohabiting pair may continually change (Preston, 1971, 1973; Castro, 1978). In addition to these adult pairs, variable numbers of juvenile symbionts usually live unmolested in the basal areas of the coral host until they grow sufficiently large to displace an adult or colonize a previously uninhabited small coral.

In contrast, the nonsymbiotic decapods which occupy dead coral surfaces are small, generally drab in color and have less tendency to pair or exclude conspecifics. Alpheus clypeatus, the most frequently found nonsymbiont, does usually occur in sex pairs, but this is an exception probably related to its residing in tubes which it constructs within algal mats growing on dead coral (Bowers, 1970). The numbers of individuals per species of other nonsymbionts on a coral host were variable and apparently random, ranging from single specimens to as many as 45 individuals per species.

Another contrasting characteristic between members of the two communities lies in their food sources and feeding habits. Examination of gut contents (Barry, 1965; Knudsen, 1967; Preston, 1971; Patton, 1974) and observations of feeding behavior (Knudsen, 1967; Patton, 1974) have indicated that the mucus produced by the coral host is the principal food source utilized by members of the decapod symbiont community. The obligate nature of this feeding relationship is indicated by the fact that when the coral is rapidly killed, all symbionts leave the coral skeleton within a few days (Glynn, 1976). The present study indicates that when the decline of the host is gradual, the numbers and biomass of the symbionts that remain on the host are proportional to the area of living tissue remaining and therefore are probably functions of the food source still available.

No information is available concerning the food preferences of the nonsymbiotic decapods which colonize dead Pocillopora meandrina. Most are probably deposit or detritus feeders, or they may utilize algae which rapidly grow on the dead coral surface. Certainly the food requirements of this group are far less restricted than those of the mucus-feeding symbionts, since nonsymbiotic species can exist independently of live coral and utilize the coral skeleton principally for habitat and protection.

The results indicate that, for both symbiont and nonsymbiont communities, available surface area is the 
principal determinant of the numbers of species and individuals present, independent of spatial heterogeneity. Although a significant linear relationship between species number and available host surface area was found for both communities, Figure 1 suggests an assymptotic curvilinear relationship to be a better representation of data for the symbiotic species. Barry (1965) found a marked difference between the numbers of symbiont species associated with large versus small, live Pocillopora meandrina colonies, and Abele and Patton (1976) also report an assymptotic relationship between numbers of associated decapod species and size of Pocillopora damicornis colonies in Panama. By contrast, the numbers of nonsymbiont species in the present study are linearly related to the dead coral surface area. It appears that, while nonsymbiont species colonize the coral strictly in proportion to the dead surface area available, symbiotically associated decapods require a live coral tissue surface area corresponding to coral volume of about $10^{3} \mathrm{~cm}^{3}$ to support a stable symbiont community. Few additional symbiotic species are added by increasing coral surface area above this lower critical value. This reflects the fact that relatively few decapods are specialized for mucus feeding, which is the basis of the obligate trophic relationship that exists between the symbiotic decapods and their coral host.

Abele and Patton (1976) found surface area, irrespective of habitat diversity, to determine the numbers of decapod species associated with Pocillopora damicornis corals. Their results substantiate the MacArthur and Wilson (1967) model, which suggests that area alone determines numbers of species by regulating population sizes above a critical extinction value. Abele and Patton (1976) examined this hypothesis by sampling decapods from different size coral hosts, thereby holding habitat heterogeneity constant but testing the effect of available surface area. The present study, by contrast, utilized coral hosts of similar sizes, but examined the effect of different habitats: live versus dead coral surface. The results indicate available surface to be the primary determinant of species richness, but suggest that the effect of habitat heterogeneity cannot be dismissed. The community associated with tissue covered, live $P$. meandrina is far less diverse than the assemblage of species that occupies the coral after it dies. The surface of the dead coral supports a variety of epiphytic calcareous and fleshy macroalgae, and the spatial heterogeneity of the microhabitats afforded by these is substantially greater than the relatively simplified surface of the living coral. The variety of food possibilities offered by the dead coral habitat is probably similarly increased.

Predation has been proposed to be an important factor for establishing and maintaining high diversity by preventing monopolization of space or resources by dominant herbivore competitors (Paine, 1966). This hypothesis has been substantiated by studies of temperate intertidal systems (Paine, 1966; Menge and Sutherland, 1976; Lubchenco and Menge, 1978), fish communities in the Florida Everglades (Kushlan, 1976) and observations of effects of Acanthaster planci predation on reef corals (Porter, 1972). It has been suggested (Kushlan, 1976; Menge and Sutherland, 1976) that the diversifying effect of predation is most strongly expressed where physical conditions are stable and communities are trophically complex, conditions indicative of the coral reef environment. However, the effect of predation on species richness is not always predictable. Day (1977) found the species richness of algae in light to be decreased by fish predation on the Great Barrier Reef while fish predation increased the species richness of invertebrates in light limited environments.

Predation was of minimal importance in determining the species composition and diversity of either the symbiont or nonsymbiont decapod communities of this study. Because of the protective habitat provided by the coral skeleton, predators are effectively excluded, although fish predation on Trapezia crabs moving between coral colonies has been observed (Preston, 1971, 1973; Castro, 1978). The nondecapods normally found on live Pocillopora meandrina are a gastropod mollusc (Quoyula madreporarum), an ophiuroid (Ophiocoma pica) and a fish (Caracanthus maculatus). Two other fishes (Scorpaena coniorta and Paracirrhites arcatus) often take refuge within $P$. meandrina branches, although they are not symbionts of the coral. None of these species has been observed to eat or otherwise molest any of the symbiotic decapods. To the contrary, Lassig (1977) has observed a similar assemblage of fish and decapods symbiotic with Pocillopora damicornis in Australia and found the decapods to attack and sometimes eat fish that were introduced into occupied coral colonies. On dead P. meandrina corals, nondecapod motile invertebrates are principally minute echinoderms, polychaetes and amphipods, all of which are incapable of feeding on the comparatively larger decapods. Fish predation on decapods living on the dead corals is probably rare because of the protection to potential prey that is provided by coral branches. Predation is therefore unlikely to be sufficient to effectively limit competition and increase diversity in either decapod community.

The high species richness and diversity of tropical coral reefs is well recognized (MacArthur, 1965; Pianka, 1966) and has been proposed as evidence that a stable physical environment over long time periods promotes speciation and evolution of high faunal diversity (Sanders, 1968; Slobodkin and Sanders, 
1969). However, recent studies of reef coral communities (Connell, 1973, 1978; Grassle, 1973); Grigg and Maragos, 1974) have indicated that species richness and diversity is increased rather than decreased by periodic physical disturbance which eliminates dominance by the best competing species and reopens habitat space for colonization.

A review by Grassle (1973) attempts to synthesize these apparently opposing viewpoints and illustrates the importance of both stable environment and periodic perturbation in developing high species richness in coral reefs. Stable physical conditions favor specialized long-lived species with low or infrequent recruitment of juveniles into the population. Population sizes required for breeding are small because of the predictability of the environment, and this results in increased homoselection and inbreeding leading to increased rates of speciation. Other aspects of high environmental predictability are increased asexual reproduction and development of interspecific biotic relationships such as symbiosis and agonistic behavior.

A completely predictable environment would likely lead to dominance by the most competitive species and a reduction in species richness if localized physical disturbances did not periodically reopen habitat space that could be colonized by opportunistic species. These are characterized by high recruitment and mortality rates, relatively short lives and large population sizes. All these are characteristics of generalist species that adapt to unpredictable environments through short term selection, and species diversity of the total reef community is further increased.

The decapod assemblages of this study illustrate both types of communities and the physical conditions which they represent. The symbiotic decapods are adapted to a highly stable physical environment, are specialized to a particular food source and maintain populations as small as one breeding pair per species for each coral head. Although they have high potential fecundity and produce abundant larvae and juveniles, recruitment into the population on each coral is restricted for most of the symbiont species by agonistic behavior, and the composition of the total community is quite predictable for a given host coral size. While the symbiont community is not highly diverse, substantial speciation has occurred, given the limited habitat available, resulting in five species of Trapezia that occur on Hawaiian Pocillopora meandrina, which are physically very similar and are differentiated principally by their coloration.

Although the symbiotic decapods apparently leave a dying coral colony principally because of the decreasing food source available, it is likely that their physiological requirements are nearly as restricted as those of the host, which has been shown to be among the most stenotopic marine species in Hawaii (Edmondson, 1928; Jokiel and Coles, 1974; Coles et al., 1976). For example, Trapezia intermedia, which is the most frequent symbiont, was found by Baldwin (1939) to be the most temperature sensitive of 19 decapods tested in Hawaii. The generalist species which rapidly colonize a dying coral head are less restricted in their physical requirements than the symbionts.

In contrast to the large-sized symbiotic decapods, the nonsymbionts are adapted for rapid propogation by minute individuals in highly varied microenvironments. The high species diversity and equitability of the decapod community which colonizes the dead coral is a reflection of the diverse characteristics of the population of decapods available for colonization from the general reef environment. The community structure of a given colonized coral is highly unpredictable and varied, and may be primarily a result of stochastic processes similar to the model proposed by Sale (1978) to explain the community structures of sites colonized by reef fishes. By this model the amount of available living space determines the upper limit of total occupants, and priority of arrival is the primary determinant of community composition. Further study would be necessary to determine the relative importance of chance colonization compared to spatial heterogeneity and interspecific competition in determining the species composition of the nonsymbiont decapod community.

\section{LITERATURE CITED}

Abele, L. G. (1974). Species diversity of decapod crustaceans in marine habitats. Ecology 55: 156-161

Abele, L. G. (1976). Comparative species richness in fluctuating and constant environments: Coral-associated decapod crustaceans. Science, N. Y. 192: 461-463

Abele, L. G., Patton, W. K. (1976). The size of coral heads and the community biology of associated decapod crustaceans. J. Biogeogr. 3: 1-13

Baldwin, P. H. (1939). A study of temperature resistance in the decapoda. M. S. thesis, University of Hawaii, Honolulu

Banner, A. H. (1953). The crangonidae, or snapping shrimp, of Hawaii. Pacif. Sci. 7: 1-147

Barry, C. K. (1965). Ecological study of the decapod crustaceans commensal with the branching coral Pocillopora meandrina var. nobilis Verrill. M. S. thesis, University of Hawaii, Honolulu

Bowers, R. L. (1970). The behavioral ecology of Alpheus clypeatus Coutiere. Ph. D. thesis, University of Hawaii, Honolulu

Castro, P. (1976). Brachyuran crabs symbiotic with scleractinian corals: A review of their biology. Micronesica 12: $99-110$ 
Castro, P, (1978). Movements between coral colonies in Trapezia Fermuginea (Crustacea, Brachyura), an obligate symbiont of scleractinian corals. Mar. Biol. 46: 237-245

Coles, S. L., Jokiel, P. L., Lewis, C. R. (1976). Thermal tolerance in tropical versus subtropical Pacific reef corals. Pacif. Sci. 30: 159-166

Connell, J. H. (1973). Population ecology of reef building corais. In: Jones, O. A., Endean, R. (eds) Biology and ecology of coral reefs, Vol. II, Biology I. Academic Press, New York, pp. 205-245

Connell, J. H. (1978). Diversity in tropical rain forests and coral reefs. Science, N. Y. 199: 1302-1310

Connell, J. H., Orias, E. (1964). The ecological regulation of species diversity. Am. Nat. 98: 399-414

Day, R. W. (1977). Two contrasting effects of predation on species richness in coral reef habitats. Mar. Biol. 44: 1-5

Edmondson, C. H. (1928). The ecology of an Hawaiian coral reef. Bull. Bernice Bishop Mus. 45: 1-64

Edmondson, C. H. (1929). Growth of Hawaiian corals. Bull. Bernice Bishop Mus. 58: 1-38

Garth, J. S. (1964). The crustacea decapoda (Brachyura and Anomura) of Eniwetok Atoll, Marshall Islands, with special references to the obligate commensals of branching corals. Micronesica 1: 137-144

Garth, J. S. (1974a). On the occurrence in the eastern tropical Pacific of Indo-West Pacific decapod crustaceans commensal with reef-building corals. Proc. 2nd Int. Coral Reef Symp. 1: $397-404$

Garth, J. S. (1974b). Decapod crustaceans inhabiting reefbuilding corals of Ceylon and the Maldive Islands. J. mar. biol. Ass. India 15: 195-212

Glynn, P. W. (1976). Some physical and biological determinants of coral community structure in the eastern Pacific. Ecol. Monogr. 46: 431-456

Goodman, D. (1975). The theory of diversity-stability relation ships in ecology. Q. Rev. Biol. 50: 237-266

Grassle, J. R. (1973), Variety in coral reef communities. In: Jones, O. A., Endean, R. (eds) Biology and geology of coral reefs, Vol. II, Biology I. Academic Press, New York, pp. $247-270$

Grigg, R. W., Maragos, J. E. (1974). Recolonization of hermatypic corals on submerged lava flows in Hawaii. Ecology 55: $387-395$

Hurlbert, S. H. (1971). The nonconcept of species diversity: a critique and alternative parameters. Ecology 52: 577-586

Johannes, R. E. (1975). Pollution and degradation of coral reef communities. In: Ferguson-Wood, E. J., Johannes, R. E. (eds) Tropical marine pollution. Elsevier, Amsterdam, pp. $13-51$

Johannes, R. E., Coles, S. L., Kuenzel, N. T. (1970). The role of zooplankton in the nutrition of some scleractinian corals. Limnol. Oceanogr. 15: 579-586

Johnson, R. G. (1970). Variations in diversity within benthic marine communities. Am. Nat. 104: 285-300

Jokiel, P. L., Coles, S. L. (1974). Effects of heated effluent on hermatypic corals at Kahe Point, Oahu. Pac. Sci. 28: 1-18

Klopfer, P. H., MacArthur, R. H. (1961). On the causes of tropical species diversity: Niche overlap. Am. Nat. 45: 223-226

Knudsen, J. W. (1967). Trapezia and Tetralia (Decapoda, Brachyura, Xanthidae) as obligate extoparasites of pocilloporid and acroporid corals. Pacif. Sci. 21: 51-57

Kohn, A. J (1971). Diversity, utilization of resources, and adaptive radiation in shallow water marine invertebrates of tropical oceanic jslands. Limnol. Oceanogr. 16: 332-348

Kushlan, J. A. (1976). Environmental stability and fish community diversity. Ecology 57: 821-825
Lassig, B. R. (1977). Communication and coexistence in a coral community. Mar. Biol. 42: 85-92

Levin, S. A., Paine, R. T. (1974). Disturbance, patch formation and community structure. Proc. natn. Acad. Sci. U.S.A. 71: $2744-2747$

Loya, Y. (1972). Community structure and species diversity of hermatypic corals at Eilat, Red Sea. Mar. Biol. 13: 100-123

Lubchenco, J., Menge, B. A. (1978). Community development and persistence in a low rocky intertidal zone. Ecol. Monogr. 59: 67-94

MacArthur, R. H. (1955). Fluctuations of animal populations and a measure of community stability. Ecology 36 : 533-536

MacArthur, R. H. (1965). Patterns of species diversity. Biol. Rev. 40: 510-533

MacArthur, R. H., Wilson, E. O. (1967). The theory of island biogeography, Princeton University Press, Princeton, New Jersey

McCain, J, C., Coles, S. L. (1979). A new species of crab (Brachyura, Hapalocarcinndae) inhabiting pocilloporid corals in Hawaii. Crustaceana, 36: 81-89

McCloskey, L. R. (1970). The dynamics of the community associated with a marine scleractinian coral. Int. Revue ges. Hydrobiol. 55: 13-81

Maragos, J. E. (1974). Reef corals of Fanning Island. Pacif. Sci. 28: $247-255$

Marsh, J. A. (1970). Primary productivity of reef-building calcareous red algae. Ecology 51: 257-263

Menge, B. A., Sutherland, J. P. (1976). Species diversity gradients: Synthesis of the roles of predation, competition, and temporal heterogeneity. Am. Nat. 110: 351-369

Paine, R. T. (1966). Food web complexity and species diversity. Am. Nat. 100:65-75

Patton, W. K. (1966). Decapod crustaceans commensal with Queensland branching corals. Crustaceana 10: 271-295

Patton, W. K. (1974). Community structure among the animals inhabiting the coral Pocillopora damicomis at Heron Island, Australia. In: Vernberg, W. B. (ed) Symbiosis in the sea, Vol. 2. University of South Carolina Press, Columbia, S. C., pp. 210-243

Patton, W. K. (1976). Animal associates of living corals. In: Jones, O. A., Endean, R. (eds) Biology and geology of coral reefs, Vol. 3, Biology 2. Academic Press, New York, pp. $1-36$

Pianka, E. R. (1966). Latitudinal gradients in species diversity: A review of concepts. Am. Nat. 100: $33-46$

Pielou, E. C. (1966). The measurement of diversity in different types of biological collections. J. theor. Biol. 13: 131-144

Porter, J. W. (1972a). Patterns of species diversity in Caribbean corals. Ecology 53: 745-748

Porter, J. W. (1972b). Predation by Acanthaster and its effect on coral species diversity. Am. Nat. 106: 487-492

Potts, F. A. (1915). Haplocarcinus, the gall-forming crab, with some notes on the related genus Cryptochirus. Pap. Dept. mar Biol. Carnegie Instn Wash. 8: 35-71

Preston, E. M. (1971). Niche overlap and competition among five congeneric species of xanthid crabs. Ph. D. dissertation, University of Hawaii, Honolulu

Preston, E. M. (1973). A computer simulation of competition among five sympatric congeneric species of xanthid crabs. Ecology 54: 469-483

Preston, F. W. (1960). Time and space and the variation of species. Ecology 41:611-627

Sale, P. F. (1978). Coexistence of coral reef fishes - a lottery for living space. Env. Biol. Fish. 3: 85-102

Sanders, H. L. (1968). Marine benthic diversity: A comparative study. Am. Nat. 102: 243-282 
Scatterday, J. W. (1977). Low-water emergence of Caribbean reefs and effect of exposure on coral diversity observations off Bonaire, Netherlands Antilles. Stud. Geology 4: 155-169
Shannon, C., Weaver, W. (1949). The mathematical theory of communication, University of Illinois Press, Urbana

Slobodkin, L. R., Sanders, H. L. (1969). On the contribution of environmental predictability to species diversity. Brookhaven Symp. Biol. 22: 82-95

This paper was submitted to the editor; it was accepted for printing on November 16, 1979. 